\title{
VIRULENCE AND AGGRESSIVENESS OF SUNFLOWER BROOMRAPE (Orobanche cumana Wallr.) POPULATIONS IN ROMANIA
}

\author{
Pacureanu Joita, M. ${ }^{*}$, Raranciuc, S. ${ }^{1}$, Sava, E. ${ }^{1}$, Stanciu, D. ${ }^{1}$, Nastase, D. ${ }^{2}$ \\ ${ }^{1}$ National Agricultural Research and Development Institute Fundulea, \\ N.Titulescu St., No.1, 915200, Fundulea, Calarasi, Romania \\ 2 Agricultural Research and Development Station, Braila
}

Received: July 15, 2009

Accepted: November 10, 2009

\section{SUMMARY}

The pathogenic composition of broomrape populations in Eastern Europe, Turkey and Spain has changed over the years, slowly at first and then rapidly. In Romania, there are three important areas infested with broomrape (Orobanche cumana Wallr.). These areas differ in infestation degree and presence of different virulence groups. A new, highly virulent population of broomrape attacked sunflower in Romania in 2006. Many commercial hybrids belonging to different companies or to research institutes lost their resistance to the parasite in a heavily infested area near the Black Sea. The sunflower differentials set for the different races of the parasite have permited to identify a new, highly virulent population of broomrape in this area. The parasite infestation degree on the hybrids resistant to the old races has showed that this population is very aggressive. Several genotypes fully resistant to this new broomrape population have been identified in the sunflower germplasm collection of Fundulea institute. These genotypes (lines) can be used as sources of resistance genes as well as for obtaining resistant hybrids.

Key words: sunflower, broomrape, virulence, resistant, sensitive

\section{INTRODUCTION}

Broomrape (Orobanche cumana Wallr./Orobanche cernua Loefl.) attacks sunflower crop in parts of Europe, the Near East and China (Vranceanu, 2000). In recent years the parasite migrated to Western Europe (in 2007 the parasite attacked the sunflower crop in France).

Sunflower breeding for resistance to this parasite was started by Pustovoit in 1912 at VNIIMK institute in Krasnodar, Russia (Sackston, 1992). By 1927, Pustovoit had selected strains with up to $99 \%$ of resistant plants (Pustovoit, 1967). By

* Corresponding author: Phone: (40)242642044; Fax: (40)242642044; e-mail: pacurean@ricic.ro,mariapacureanu2@yahoo.com 
that year, however, previously resistant sunflowers started succumbing to what turned out to be a complex of new broomrape races.

The virulence of the parasite populations has changed over the years. Vranceanu et al. (1980) reported on five virulence groups (races or groups of races) of broomrape encountered in Romania, and five types of resistance effective against the respective groups. These investigators set up a series of differentials permitting identification of the five virulence groups, although not the individual races of the pathogen as each resistance type was effective against a specific race group. The results of complex crossing studies demonstrated a gene-for-gene relationship between the virulence groups of broomrape and resistance in sunflower. They successfully introduced the gene $\mathrm{Or}_{5}$, which provides resistance to all five race groups, into inbred lines with high combining ability that became parents to the subsequently released resistant hybrids.

In 1995, a new race, overcoming all the known resistance genes, $\mathrm{Or}_{1}$ through $\mathrm{Or}_{5}$, was identified in Spain, and it was named $\mathrm{F}$ race (Alonso et al., 1996). Resistance to this new race was found in germplasm of both cutivated and wild sunflower (Fernandez-Martinez et al., 2000). In 1996, the race F of the parasite was identified in the sunflower crop in Romania, as well as the gene conferring resistance to this race (Pacureanu, 1998). A more virulent race, named race $\mathrm{G}$, attacking the cultivars resistant to the race $\mathrm{F}$, has been identified in Spain (Molinero- Ruiz and MeleroVara, 2005). Virulent races overcoming the resistance gene $\mathrm{Or}_{5}$ were also identified in Turkey, where the new races seemed to be more virulent than the races in other countries (Kaya et al., 2004).

Starting in 2006, in some regions of Rusia, a new, highly virulent population of broomrape was registered (Tatiana Antonova, personal communication ).

This paper presents the results obtained in identifying a new race or complex of races of Orobanche cumana in the sunflower crop in Romania, as well as some sources of resistance to the parasite.

\section{MATERIAL AND METHODS}

Different sunflower hybrids have been used for tests in fields naturally infested with broomrape, in two important sunflower-growing areas in Romania. The investigators used a series of differentials permitting identification of different virulence groups of the parasite. The different sunflower genotypes (lines and populations) have been tested for resistance to the broomrape, with a view to identify new sources of resistance to the most virulent populations of the parasite. Test were also performed under artificial inoculation using broomrape seeds collected in two highly infested areas in Romania. The pots of 51 volume filled with a mixture of sand, earth and broomrape seeds were used in the tests in the artificial infestation conditions. 


\section{RESULTS AND DISCUSSION}

In Romania, more than $60 \%$ of the sunflower cultivated area are infested with broomrape. There are three important areas differing in infestation degree and the presence of different virulence groups (Figure 1). The high infestation degree in the first area, situated near the Black Sea, is given by a broomrape population more virulent than the race E. In the second area, situated in Ialomita-Braila, the broomrape population is more virulent than the race $\mathrm{E}$, but not as agressive as the one in the first area. In both of these areas one, two or more new races of the parasite could be present.

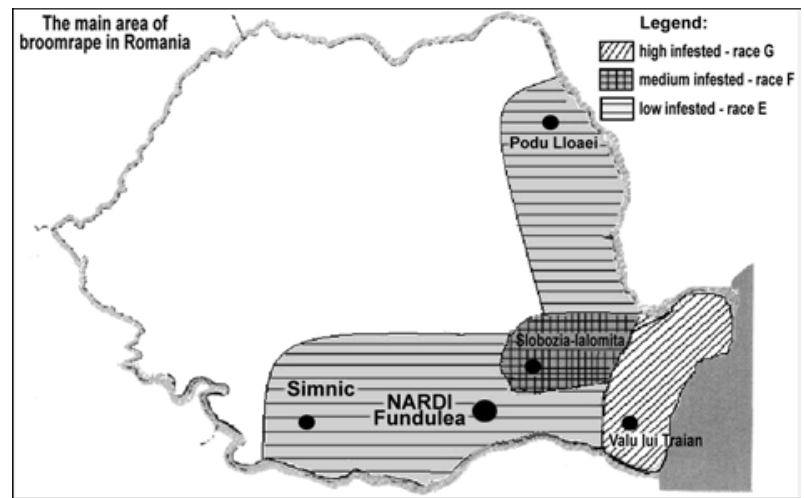

Figure 1: The main areas of broomrape infestation in the sunflower crop in Romania

The third area, situated in in the east and part of south Romania has a population of broomrape having ahigh percentage of the race $\mathrm{E}$, but, in 2008 , in some places not far from Fundulea, a new population was identified which was more virulent than the race $\mathrm{E}$.

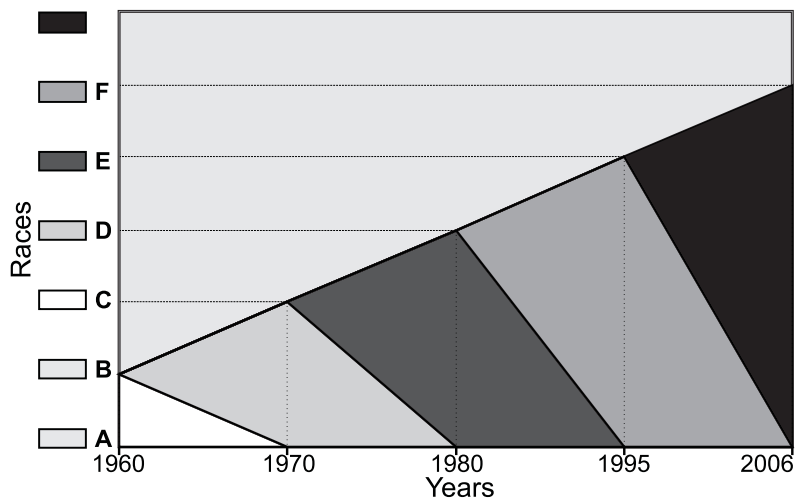

Figure 2: The spread of the broomrape races in sunflower crop in Romania

In recent years, the parasite Orobanche cumana has developed new races in the sunflower crop in Romania in a shorter time compared with the first period (Figure 2). While more than 25 years passed from the identification of races A and 
$\mathrm{B}$ to $\mathrm{E}$ race, in the last 15 years, the parasite developed 2 new and virulent populations, one of which has quickly spread over a large area.

In 2006, in the sunflower crop in Tulcea area, near the Black Sea, some of the hybrids resistant to the most virulent population of the parasite existing in this area (named race F), were severely attacked by broomrape (Figure 3). Only two hybrids remained resistant in that area and in that year. The same hybrids cultivated in Braila-Ialomita area were not infested with broomrape (Figure 4).

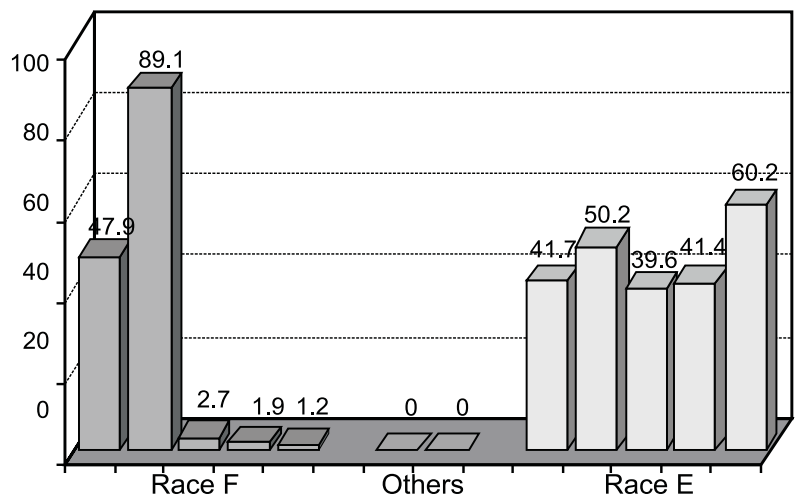

Figure 3: Behaviour of some sunflower hybrids cultivated in Tulcea area infested with broomrape, Romania, 2006

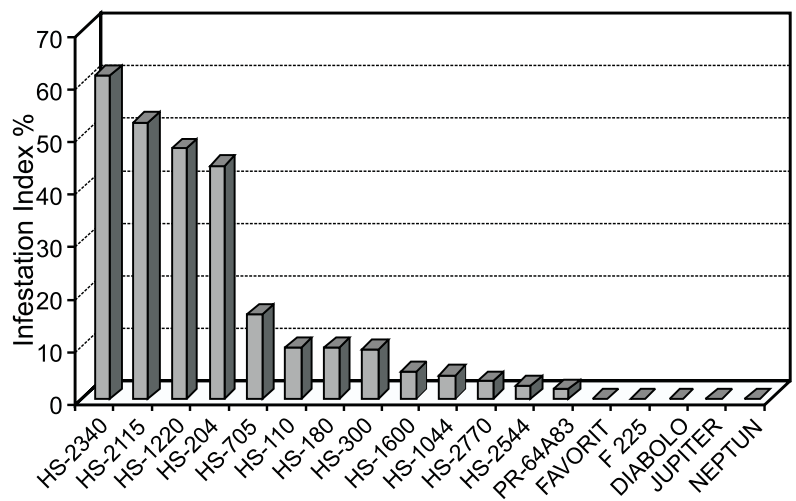

Figure 4: Behaviour of some sunflower hybrids resistant to the attack of Orobanche cumana in Braila-Ialomita area, 2006

Using differential lines and some hybrids with known reaction to the broomrape races in Romania, we have performed tests in artificial infestation conditions using broomrape seeds collected in the area infested with the new population of the parasite, as well as in the area infested with the old population (Braila-Ialomita). The results presented in Table 1 show that the differential for the race $F$, the inbred line LC 1093, lost its resistance in Tulcea area, but was fully resistant in Braila-Ialomita area. The same behaviour was shown by the hybrids which have that line as the female parent (Favorit and F 225). 
The two new Fundulea hybrids and the hybrid PR64A71 suffered very low broomrape attacks, one of the former being fully resistant.

Table 1: Reaction of different sunflower genotypes to Orobanche cumana attack (Fundulea, 2007-2008)

\begin{tabular}{|c|c|c|c|c|c|}
\hline \multirow{3}{*}{$\begin{array}{l}\text { Sunflower } \\
\text { genotype }\end{array}$} & \multirow{3}{*}{$\begin{array}{l}\text { Reaction to } \\
\text { the broomrape } \\
\text { races }\end{array}$} & \multicolumn{4}{|c|}{ Source of broomrape } \\
\hline & & \multicolumn{2}{|c|}{ lalomita -Braila } & \multicolumn{2}{|c|}{ Tulcea - Constanta } \\
\hline & & $\begin{array}{l}\text { No. of infested } \\
\text { sunfl. plants }\end{array}$ & $\begin{array}{l}\text { Infestation } \\
\text { degree (\%) }\end{array}$ & $\begin{array}{l}\text { No. of infested } \\
\text { sunfl. plants }\end{array}$ & $\begin{array}{l}\text { Infestation } \\
\text { degree (\%) }\end{array}$ \\
\hline$P-1380-2$ & $E-A$ & $10 / 10$ & 53.7 & $10 / 10$ & 71.9 \\
\hline LC-1093 & $F-A$ & $0 / 10$ & 0.0 & $3 / 10$ & 9.7 \\
\hline AO-548 & New - A & $0 / 10$ & 0.0 & $0 / 10$ & 0.0 \\
\hline RS-832 & New - A & $0 / 10$ & 0.0 & $0 / 10$ & 0.0 \\
\hline Favorit & $F-A$ & $0 / 10$ & 0.0 & $7 / 10$ & 12.4 \\
\hline F-225 & $F-A$ & $0 / 10$ & 0.0 & $6 / 10$ & 11.8 \\
\hline PR64A71 & New -A & $0 / 10$ & 0.0 & $4 / 10$ & 3.9 \\
\hline HS 2020 & New - A & $0 / 10$ & 0.0 & $2 / 10$ & 0.7 \\
\hline HS 2134 & New - A & $0 / 10$ & 0.0 & $0 / 10$ & 0.0 \\
\hline
\end{tabular}

In 2008, in Calarasi district, intensive attack was registrated on some sunflower hybrids thought to be fully resistant to race E. For this reason, we have tested some sunflower differentials for reaction to broomrape races, using broomrape seeds collected from this area. The results are presented in Table 2. The differential for race F (LC 1093) was not attacked. The differential for race $E$ was attacked at a high percent. So, it is clear that a new, virulent population of the parasite overcame the resistance to race $\mathrm{E}$ in this area.

Table 2: Reaction to broomrape attack in artificial infestation conditions (Fundulea, 2008)

\begin{tabular}{lcc}
\hline Sunflower genotype & Reaction to the broomrape races & Infestation degree (\%) \\
\hline P-1380-2 & E - A & 35.7 \\
LC-1093 & F - A & 0.0 \\
Favorit & F - A & 1.4 \\
PR64A71 & New - A & 0.0 \\
AO-548 & New - A & 0.0 \\
AD-66 & Sensitive & 67.5 \\
\hline
\end{tabular}

\section{CONCLUSION}

The parasite Orobanche cumana has became increasingly more dangerous for the sunflower crop in Romania. In 2006, most of the resistant sunflower hybrids cultivated in the area infested with this parasite, were attacked. Some of them suffered intensive attacks (80\%). The behavior of some sunflower differentials for the broomrape races has showed the parasite's virulence is increasing. Even in the area having the fields infested by race $\mathrm{E}$ of the parasite, the hybrids lost their resistance to broomrape. It seems that the new and virulent populations of the parasite are spreading quickly. 


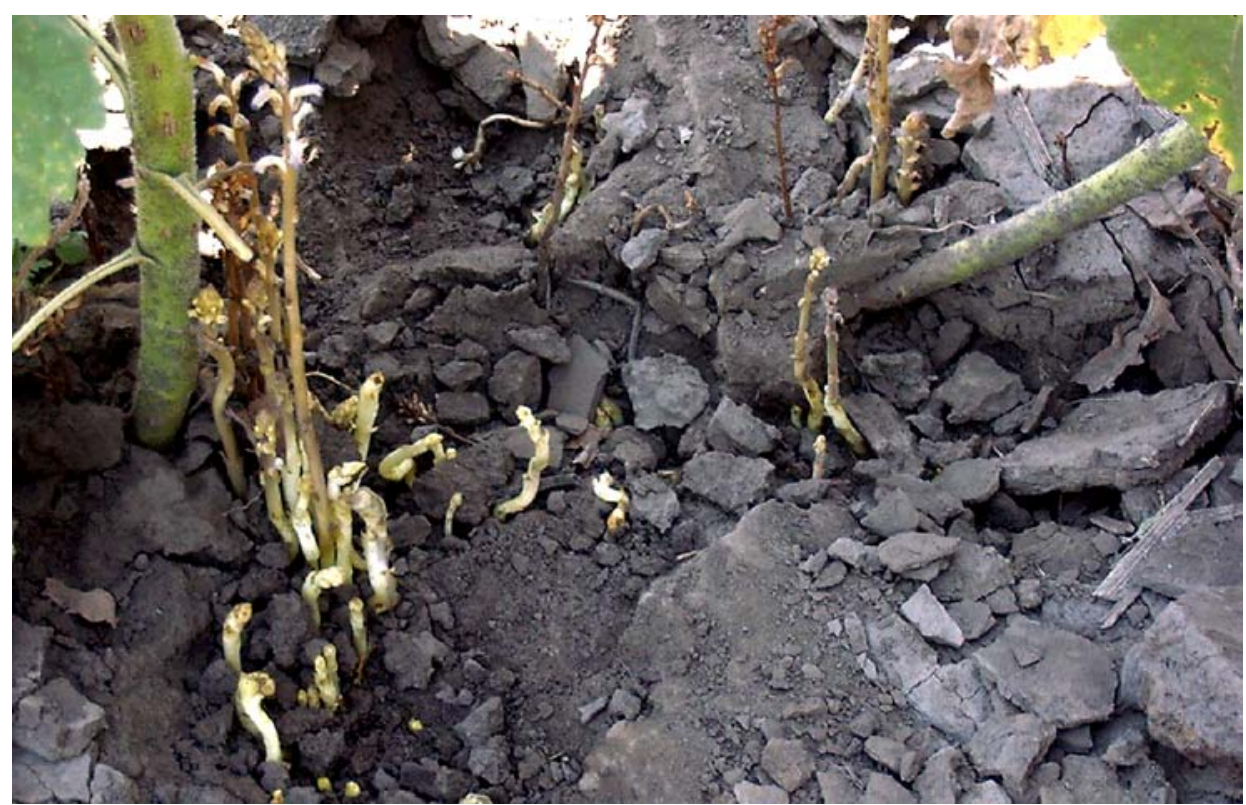

Figure 5: The high infestation with broomrape in Romania

\section{REFERENCES}

Alonso, L.C., Fernandez-Escobar, J., Lopez, G., Rodiguez-Ojeda, M., Sallago, F., 1996. New highly virulent sunflower broomrape (Orobanche cernua Loefl.) pathotype in Spain. Proc. $6^{\text {th }}$ Int. Symp. Parasitic Weeds. Cordoba, Spain, 16-18 April 1996 pp. 639-644.

Fernandez-Martinez, J.M., Melero-Vara, J.M., Munoz-Ruz, J., Ruso, J., Dominguez, J., 2000. Selection of wild and cultivated sunflower for resistance to a new broomrape race that overcomes resistance to $\mathrm{Or}_{5}$ gene. Crop Sci. 40: 550-555.

Kaya, Y., Evci, G., Pekcan, V., Gucer, T., 2004. Determining new broomrape-infested areas, resistant lines and hybrids in Trakya region of Turkey. Helia 27(40): 211-218.

Molinero-Ruiz, M.L., Melero-Vara, J.M., 2005. Virulence and aggressiveness of sunflower broomrape populations overcoming the $\mathrm{Or}_{5}$ gene. In: Seiler, G.J. [ed.], Proc. $16^{\text {th }}$ Int. Sunflower Conference, Fargo, ND, August 29-September 2, 2004 pp. 165-169.

Pacureanu-Joita, M., Vrânceanu, A.V., Soare, G., Marinescu, A., Sandu, I., 1998. The evaluation of the parasite-host interaction in the system Helianthus annuus L. - Orobanche cumana Wallr. in Romania. Proc. $2^{\text {nd }}$ Balkan Symposium on Field Crops, Vol.1: 153-158.

Pustovoit, V.S., 1967. Handbook of Selection and Seed Growing of Oil Plants (In Russian) Transl. 1973, Jerusalem: Isr.Progr.Sci.Transl., pp.1-35.

Sackston, W.E., 1992. On a treadmill: Breeding sunflowers for resistance to disease. Annu.Rev.Phytopathol. 30: 529-551.

Vranceanu, A.V., 2000, Floarea soarelui hybrida. Editura Ceres, Bucuresti.

Vranceanu, A.V., Tudor, V.A., Stoenescu, F.M., Pârvu, N., 1980. Virulence groups of Orobanche cumana Wallr., differential hosts and resistance sources and genes in suflower. In: Proc. $9^{\text {th }}$ Int. Sunflower Conf., Torremolinos, Spain. 8-13 July 1980. Int. Sunflower Assoc., Paris 1:74-82. 


\title{
VIRULENCIA Y AGRESIVIDAD DE POBLACIONES DE JOPO DE GIRASOL (Orobanche cumana Wallr.), EN RUMANIA
}

\author{
RESUMEN
}

En Europa del este, Turquía y España, la composición de las poblaciones de jopo ha cambiado primero lentamente y, luego, rápidamente a través de los años. En Rumania hay tres áreas importantes infestadas con jopo (Orobanche cumana Wallr.), con grado de infestación distintos y con presencia de grupos con diferente virulencia. Una nueva población altamente virulenta de jopo ha atacado girasol en Rumania en el año 2006. Muchos híbridos comerciales de diferentes empresas e institutos de investigación perdieron su resistencia al parásito, en una zona muy infestada cerca del Mar Negro. El set diferencial de girasol para las diferentes razas del parásito permitió identificar una nueva y más virulenta población de jopo, en esa área. El grado de infestación de los híbridos resistentes a las razas antiguas ha demostrado que esta nueva población es muy agresiva. En la colección de germoplasma girasol del Instituto de Fundulea han sido identificados algunos genotipos, completamente resistentes a esta nueva población de jopo. Estos genotipos (líneas) pueden utilizarse como fuente de resistencia para la transferencia de genes así como, directamente, en la obtención de híbridos resistentes.

\section{VIRULENCE ET AGRESSIVITÉ DE POPULATIONS DE L'Orobanche DU TOURNESOL (Orobanche cumana Wallr.) EN ROUMANIE}

\author{
RÉSUMÉ
}

La composition des populations du pathogène Orobanche a changé au cours des années, lentement d'abord puis rapidement en Europe de l'Est, en Turquie et en Espagne. En Roumanie, il y a trois zones importantes infestées par l'Orobanche (Orobanche cumana Wallr.), avec divers degrés d'infestation et présence de plusieurs groupes de virulence.

Une nouvelle population fortement virulente d'Orobanche a attaqué le tournesol en Roumanie en 2006. De nombreux hybrides commerciaux appartenant à différentes sociétés ou aux instituts de recherche ont perdu leur résistance à ce parasite, dans un secteur très infesté situé près de la Mer Noire.

Les différentiels de tournesol établis pour les diverses races du parasite ont permis d'identifier une nouvelle population plus virulente d'Orobanche dans cette région. Le degré d'infestation par le parasite sur les hybrides résistants aux anciennes races a prouvé que cette population est très agressive.

Dans la collection de matériel génétique de tournesol de l'Institut de Fundulea ont été identifiés quelques génotypes complètement résistants à cette nouvelle race d'Orobanche.

Ces lignées peuvent être employées aussi bien comme source de résistance pour le transfert de gènes que pour l'obtention directe d'hybrides résistants. 
